\title{
Kard. Karol Wojtyła, Kościół w tajemnicyodkupienia. Interpretacja Vaticanum II, red. A. Dobrzyński, Fundacja Jana Pawła II. Ośrodek Dokumentacji i Studium Pontyfikatu w Rzymie, Rzym 2012, s. 462.
}

W Roku Wiary, w pięćdziesiątą rocznicę rozpoczęcia Soboru Watykańskiego II, Ośrodek Dokumentacji i Studium Pontyfikatu Jana Pawła II w Rzymie wydał niezwykle cenną pozycję ukazującą rozumienie Soboru przez kardynała Karola Wojtyłę. Książka ta pod redakcją dyrektora Ośrodka, księdza dra Andrzeja Dobrzyńskiego, stanowi swoistą kontynuację wcześniejszych badań, których rezultatem było wydanie kazań i konferencji arcybiskupa wygłaszanych w latach 1962-1966 (por. abp Karol Wojtyła, Odnowa Kościoła i świata. Refleksje soborowe, KrakówRzym 2011). Tym razem ks. A. Dobrzyński zebrał w jednym tomie opracowania o charakterze teologicznym i duszpasterskim, na które składają się głównie referaty z sympozjów naukowych i spotkań duszpasterskich, a także rezultaty prac Karola Wojtyły w ramach Konferencji Episkopatu Polski. Materiał ten stanowi bezcenne źródło do studium nauczania Błogosławionego i konieczne dopełnienie takich jego pozycji jak U podstaw odnowy. Studium o realizacji Vaticanum II (1972) czy Osoba i czyn (1969). Warto też czytać Kościót w tajemnicy odkupienia. Interpretacja Vaticanum II wraz z opublikowanymi tekstami soborowych wystąpień Błogosławionego (por. R. Skrzypczak, Karol Wojtyła na Soborze Watykańskim II. Zbiór wystapień, Warszawa 2011). Niewątpliwie olbrzymim atutem omawianego tomu jest fakt, że stanowi on najobszerniejszy zbiór tekstów późniejszego papieża, dotyczący nauczania Vaticanum II. Co więcej, na 34 teksty z lat 1965-1977, aż 11 ukazało się po raz pierwszy w tym zbiorze!

Teksty kardynała Wojtyły zostały zaprezentowane według klucza merytoryczno-chronologicznego w czterech rozdzia- łach. Pierwszy rozdział pod tytułem Poznać Sobór (s. 23-85) grupuje następujące rozprawy na temat pracy Soboru i właściwego ukazania jego doktryny: Sprawozdanie z prac soborowych zwiazanych ze schematem Konstytucji duszpasterskiej „Kościół w świecie wspótczesnym”, Vaticanum II a praca teologów, Udział biskupów polskich w Soborze Watykańskim II, Synteza myśli soborowej, Znaczenie konstytucji "Dei verbum” $w$ teologii, Teologia i teologowie w Kościele posoborowym. Teksty te powstały w pierwszych latach po zakończeniu Soboru. Ten wstępny rozdział ukazuje niejako ,warsztat" pracy biskupów i teologów oraz zasadnicze spojrzenie Karola Wojtyły na dokumenty soborowe według klucza: Ecclesia ad intra i Ecclesia ad extra. Klucz ten stanowi podstawę wyodrębnienia dwóch kolejnych rozdziałów. Drugi rozdział zatytułowany Kościót w Chrystusie (s. 89-226) obejmuje powstałe głównie w latach siedemdziesiątych teksty o następujących tytułach: Idea Ludu Bożego i świętości Kościoła a posłannictwo świeckich, Teologia laikatu, Wychowanie do stużby Kościołowi, Apostolstwo świeckich, Apostolstwo świeckich jako uczestnictwo w podstawowych funkcjach Kościoła, Świeccy w apostolstwie Kościoła, Biskup - sługa wiary, Teologiczne podstawy duszpasterskiej misji kapłana, Inspiracja maryjna Vaticanum II, Odpowiedzialność za Kościót, Struktury Kościoła a wspólnota Ludu Bożego. Jak widać, teksty te stanowią przede wszystkim komentarz do konstytucji dogmatycznej Lumen gentium i krążą wokół idei Ecclesia ad intra, skupiając się na roli świeckich w Kościele. Z kolei trzeci rozdział, zatytułowany Kościół w świecie dotyczy Ecclesia ad extra i komentuje zasadniczo konstytucję duszpasterską Gaudium et spes wraz z istotnym punktem dotyczącym 
relacji Kościoła do świata, mianowicie kwestią wolności religijnej, omawianej w deklaracji Dignitatis humanae. Również ten rozdział skupia pisma Karola Wojtyły powstałe w latach siedemdziesiątych: Wspólnota ludzka w oczach Soboru, Znaczenie Konstytucji pastoralnej dla teologów, Wychowanie do pełni kultury, Notatki na marginesie konstytucji „Gaudium et spes”, Wolność religijna jako podstawa normalizacji stosunków między państwem a Kościołem, Perspektywa człowieka - integralny rozwój a eschatologia, Konsekracja świata-granice autonomii doczesności, Prawa osoby w świetle Soboru Watykańskiego II i Synodu Biskupów w 1974 r. (por. s. 231-326). Wreszcie ostatni rozdział Realizacja Vaticanum II (s. 331-437) w logiczny sposób obejmuje następujące, powstałe w drugiej połowie lat sześćdziesiątych i na początku siedemdziesiątych artykuły: Logika wewnettrzna Vaticanum II, Problem recepcji Vaticanum II, Problem realizacji Soboru $w$ Polsce, Plan duszpasterski związany z realizacja Soboru $w$ Polsce, Realizować Sobór w życiu osobistym, Realizacja soboru a struktury diecezjalne, Udział świeckich $w$ życiu parafii. Rozdział ten dotyczy wprowadzonego przez autora i wciąż niezwykle aktualnego rozróżnienia percepcji Soboru od jego realizacji.

Ten niezwykły zbiór tekstów Karola Wojtyły pokazuje wyraźnie, że dla przyszłego papieża uroczyste nauczanie Soboru nie było jakimś najmniejszym wspólnym mianownikiem poglądów uczestników, ale prawdziwą mową Ducha Świętego do Kościoła. Wystarczy dla przykładu przypomnieć, że arcybiskup Wojtyła domagał się dla Matki Bożej innego miejsca niż ostanie w dokumencie o Kościele. Tymczasem Sobór postanowił mówić o Maryi w ósmym, ostatnim rozdziale konstytucji Lumen gentium (por. R. Skrzypczak, Karol Wojtyła na Soborze Watykańskim II. Zbiór wystapień, Warszawa 2011, s. 215-220). Niedługo później w komentarzu do konstytucji błogosławiony napisał: „wiadomo, że rozdział ósmy, mariologiczny jest ostatnim rozdziałem tego dokumentu. Równocześnie jednak można powiedzieć, że poprzez ten rozdział [...] można jakby w soczewce zobaczyć całość Konstytucji o Kościele i odczytać w niej pośrednio całą prawdę o Kościele, jaką Sobór zamierzał wypowiedzieć" (s. 202n). Widać tu odczytanie przez autora mowy Ducha do Kościoła, która zbiegła się z nadaniem przez papieża Pawła VI Bogurodzicy tytułu Matki Kościoła. Karol Wojtyła tak pisał o tym wydarzeniu: „Z punktu widzenia Magisterium i jego rozwoju w Kościele tytuł Matka Kościoła pozostanie na zawsze już wyrazem owego wprowadzenia mariologii do eklezjologii, jakie dokonało się na Soborze Watykańskim II" (s. 196).

Nawet pobieżna lektura omawianego tomu pokazuje dobitnie, że najwięcej miejsca w analizie Soboru Karol Wojtyła poświęca właśnie eklezjologii. Warto przypomnieć, że jako papież Jan Paweł II już na początku wyznaczył za główne kryterium pontyfikatu wierność Soborowi, szczególnie w wymiarze eklezjologicznym (por. Primo radiomessaggio „Urbi et Orbi”, 17 X 1978, [w:] Insegnamenti di Giovanni Paolo II, I/1978, Libreria Editrice Vaticana 1979, s. 6). Analiza całości papieskiego nauczania zawartego w Insegnamenti pokazuje, jak bardzo błogosławiony korzystał z nauczania soborowego, stosując hermeneutykę reformy, czyli wierność Tradycji i ciągłość dziejów jednego podmiotu, którym jest Kościół, oraz dążenie do wyrażania odwiecznej prawdy Bożej w nowy sposób, odpowiadający wyzwaniom współczesności. W recenzowanym tomie widać, że dla Karola Wojtyły synteza myśli soborowej mieści się w odpowiedzi na pytanie: „Ecclesia, quid dicis de te ipsa?". Odpowiedź ta sprowadza się do programu accomodata renovatio, czyli aggiornamento (udzisiejszenie) w ramach schematu Ecclesia ad intra - Ecclesia ad extra lub innymi 
słowy „świadomość Kościoła - dialog”. Obie ogniskowe dotyczą w dużej mierze kluczowego zdaniem kardynała tematu roli wiernych świeckich w Kościele i świecie. Znamienne jest, że większość zawartych w tomie tekstów dotyczy laikatu. Zainteresowanie to potwierdza fakt, że z inicjatywy kardynała Wojtyły odbył się Duszpasterski Synod Archidiecezji Krakowskiej (1972-1979), w którym uczestniczyli nie tylko duchowni, ale i wielu świeckich. Celem Synodu była recepcja doktryny Vaticanum II w archidiecezji krakowskiej, z uwzględnieniem teologicznej myśli Metropolity, że idea udziału wiernych w potrójnej misji Chrystusa jest kluczem do zrozumienia doktryny soborowej: „Świecki inaczej bytuje w Kościele, niż to przeciętnie mniemano dotąd. Bytuje na zasadzie uczestnictwa «w kapłańskim, prorockim i królewskim urzędzie Chrystusa». Myślę, że w tym miejscu czeka nas najwięk- sza praca: uświadomić świeckim ten ich teologiczny status" (s. 92). Powyższe tezy potwierdza fakt, że Nadzwyczajny Synod Biskupów zwołany w dwudziestą rocznice zakończenia Vaticanum II w 1985 roku zaowocował adhortacją apostolską Christifideles laici. Z tego względu recenzowana pozycja wydaje się nieodzowna w badaniach nad teologią laikatu. Bardzo trafną zachętę do jej lektury sformułował redaktor tomu ks. dr A. Dobrzyński: „Można żywić nadzieję, że zebrane pisma soborowe Metropolity krakowskiego będą stanowić istotną pomoc w lepszym poznaniu myśli bł. Jana Pawła II z okresu przed pontyfikatem, a zarazem ich publikacja będzie również znaczącym przyczynkiem do pogłębienia debaty dotyczącej aktualności, historycznego znaczenia i hermeneutyki Soboru Watykańskiego II" (s. 19).

ks. Wojciech Zyzak 